УДК 633.15: 577.34:58.087

\title{
QUALITY TRAITS OF MAIZE INBRED LINES AND HYBRIDS WITH EFFICIENT PHOTOSYNTHETIC FUNCTIONS
}

\author{
Č.N. RADENOVIĆ ${ }^{1,2}$, D.M. GRODZINSKIJ ${ }^{3}$, M.R. FILIPOVIĆ ${ }^{1}$, N.S. DELIĆ ${ }^{1}$, \\ J.Z. SRDIĆ 1 , I.M. PAVLOV ${ }^{1}$ \\ 1 Maize Research Institute «Zemun Polje» \\ 1 Slobodana Bajića, 11080, Belgrade, Republic of Serbia \\ radenovic@sbb.rs \\ ${ }^{2}$ University of Belgrade \\ 1 Studentski Trg, 11000, Belgrade, Republic of Serbia \\ ${ }^{3}$ Institute of Cell Biology and Genetic Engineering, National Academy of Sciences of \\ Ukraine \\ 148 Acad. Zabolotnogo St., 03143, Kyiv, Ukraine
}

This study confirms the hypothesis that new and prospective maize inbred lines and hybrids possess dominant property of an efficient photosynthetic model. This and other relevant traits are successfully used in breeding programmes, modern technologies of seed and commercial maize production. This statement is supported by the displayed results on the erect position of the top leaves of new maize inbred lines and photosynthetic and fluorescence parameters: the change of the delayed chlorophyll fluorescence intensity during its course and dynamics, the Arrhenius criterion for the determination of critical temperatures (phase transition temperatures) and the activation energies, as a measure of conformational changes in chloroplasts and thylakoid membranes. Furthermore, a grain structure including its physical and chemical properties of new maize inbred lines and hybrids was analyzed in the present study. In addition, breeding procedures, seed production, technological traits, properties and parameters of new and prospective maize inbred lines and maize hybrids were observed in the present study. Presented results show that properties of these inbred lines and maize hybrids are based on the nature of conformational and functional changes that occur in their chloroplasts and thylakoid membranes, as well as, on progressive effects in maize breeding, seed production and commercial maize production.

Key words: Zea mays L., delayed chlorophyll fluorescence, efficient photosyntheticfluorescence model, thylakoid membrane.

Maize breeding and seed production have been intensively developing for the last 65 years and because of such activity over 1400 grain and silage hybrids were derived. Modern equipment and technical and technological prerequisites were provided for carrying out the process of breeding and hybrid and commercial maize seed production [8, 21, 23]. Since 1978, the number of plants per area unit (plant density) has been significantly increased, which mostly affected the increase in grain yields [20]. At the same time, a programme of breeding and seed production of maize hybrids that included inbreds with erect top leaves has been performed [6, 18]. Maize plants architecture is a major contributing factor to their high level of productivity [26]. Varieties with an erect-leaf-angle phenotype have an increased ability of light harvesting for 
photosynthesis and grain-filling which results in elevated grain yields. Besides that, an erect leaf trait also contributes to maize grain yield by allowing for increased planting densities [5, 24].

The studies on maize photosynthesis carried out in the previous period did not have a more important application in breeding and the maize hybrid seed production. Although, some research revealed sufficient genetic variability among maize inbred lines for physiological traits [4], it was almost impossible to present practical results and a clear and direct interrelationship among photosynthesis, breeding and the production of maize hybrid seed by an old and traditional approach. The way out was found in the functional connection of photosynthetic functions with fluorescence [19, 21].

During the last 40 years, new and significant studies within the field of bioluminescence and fluorescence phenomena and processes within the plant systems, including maize, have been carried out $[1-3,7,9,12,14,17]$. The direct dependence of the delayed chlorophyll fluorescence (DF) intensity on changes of photosynthetic processes in chloroplasts and thylakoid membranes of maize intact leaves was determined [17]. Conditions that provided monitoring of complex photosynthetic processes in the intact leaf of maize inbreds by a photosynthetic and fluorescence model in the form of chlorophyll DF were developed by Radenović [19, 21].

Research methods within the field of biophysical chemistry contributed to diversified binding of studies on photosynthetic and transport processes in chloroplasts and the thylakoid membranes and different chemical structures of grain with processes of fluorescence spectroscopy and chemical kinetics [17, 19].

The complex and interrelated processes in fundamental, multidisciplinary and applied sciences are necessary in current studies. This manuscript presents the bonds of interrelated studies carried out within breeding, photosynthesis, fluorescence, biophysical chemistry and seed production in new and prospective maize inbred lines and hybrids with efficient photosynthetic functions.

The objective of the present study was to show that new and prospective inbred lines that are included into new high yielding maize hybrids could have an efficient photosynthetic model and could contribute to the functional connection of breeding, photosynthesis and fluorescence, and thereby to the overall maize breeding progress and hybrid seed production and production of commercial maize. According to our hypothesis, new and prospective maize inbred lines with erect leaves are the closest to the assumptive maize photosynthetic model.

\section{Material and Methods}

Plant material. This study was performed with the following two new and prospective maize inbred lines: ZPPL 218 and ZPPL 318 and the hybrids which have one of those inbreds as parental lines: ZP 600, ZP 606 and ZP 666 (Fig. 1). The observed inbreds and maize hybrids are developed in Maize Research Institute «Zemun Polje», Belgrade, Serbia.

The measure of an angle and leaf area. An erect position of the top leaves was studied in the series of experiments. A specially designed protractor was used to measure the angle between the position of the above-ear leaf and the plant stalk of inbred lines. The leaf area was measured by using the portable area meter (model LI-3000). Measures of the angle between the above-ear leaf and the stalk and of the leaf areas were carried out on 218 plants for each 

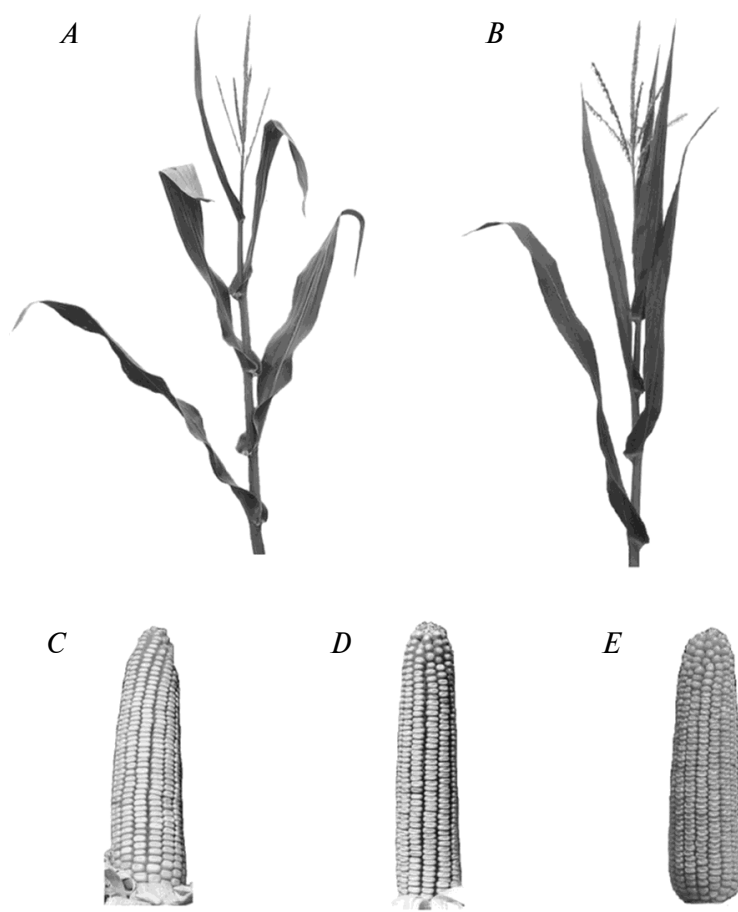

$D$

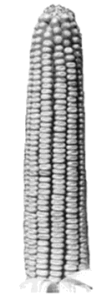

E

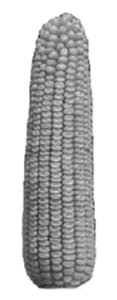

Fig. 1. Actual appearance of new inbred lines with erect top leaves: ZPPL $218(A)$, ZPPL $318(B)$, and of prospective hybrids with their ears: ZP $600(C)$, ZP $606(D)$ and ZP $666(E)$

inbred line during the three-year period. These methodical procedures were described in previously published papers [18].

Photosynthetic fluorescence measurements. Another series of the experiments was related to photosynthetic-fluorescence measurements, including thermal processes of DF, critical phase transition temperatures and activation energies. The test maize inbreds, grown at the experimental field of the Maize Research Institute «Zemun Polje», were brought to the laboratory between 7 a.m. and 8 a.m. Plants sampled in the field were transversally cut at the ground internode. In the laboratory, plants were internode lengthwise placed in water. Prior to the fluorescence experiment, all plants were kept under the black ball glass for two hours. Segments of above-ear intact leaves were taken from such plants and placed into the phosphoroscope chamber. The intact leaf segments were kept in the chamber (in the dark) for at least 15 minutes, and then thermal processes of DF were measured. These tests were performed on 168 plants of each maize inbred line.

The improved non-invasive photosynthetic fluorescence method used to measure DF, developed at the Maize Research Institute «Zemun Polje», has been improved several times. Photosynthetic fluorescence measurements were performed after a method that has been described in previously published papers [17, 19].

Yields of new and prospective maize hybrids on different locations in Serbia. Grain yields of maize hybrids ZP 600, ZP 606 and ZP 666 were observed on eight different locations in Serbia with the application of standard methods for a contemporary maize production [19].

Grain chemical composition, physical properties of new and prospective maize inbred lines and hybrids with efficient photosynthetic functions. Methods used for 
the determination of grain chemical composition and physical properties of maize inbred lines and hybrids with erect top leaves were fully described in previously published papers [19]. Grain chemical composition encompassed analysis of starch, proteins, oil and crude fibre. Physical properties of the grain are presented through 1000-grain weight (TKW), test weight (TW), density (D), floatation index (FI), milling response (MR), hard endosperm fraction (HEF) and soft endosperm fraction (SEF).

\section{Results and discussion}

1. The measure of the angle and the area of the above-ear leaf. The angles between the above-ear leaf and the stalk were $22.1^{\circ}$ and $21.2^{\circ}$ for the two examined inbreds ZPPL 218 and ZPPL 318 (Tab. 1). These inbred lines are the final products of the intensive studies of development of maize inbred lines with erect top leaves carried out at the Maize Research Institute «Zemun Polje».

2. Empirical procedure for photosynthetic fluorescence studies on the aboveear leaf. The detailed studies on thermal processes of DF of observed new maize inbred lines with erect top leaves were performed. The thermal curve is a curve that shows the dynamics of changes in the stationary DF level intensity in dependence on a temperature. The trend of its establishment is usually analogous to changes in the duration in seconds, which was determined by the empirical procedure [19].

Monitoring the course of the thermal curve and the analysis of the duration of certain segments provided data on the existence of a greater number of critical temperatures (phase transition temperatures) at which greater or smaller structural and functional changes occurred in chloroplasts and the thylakoid membranes of observed new maize inbred lines with erect top leaves.

3. The exact temperature dependence of the delayed chlorophyll fluorescence intensity for the thylakoid membranes of the maize inbred lines with erect top leaves. The experimental measures of changes in the stationary DF level in dependence of the temperature, ranging from 25 to $60{ }^{\circ} \mathrm{C}$, were performed and the dynamics of temperature dependence for two maize inbred lines with erect top leaves was observed (Fig. $2 A$ and $B$ ).

4. The Arrhenius plot for the determination of critical temperatures and conformational changes in chloroplasts and the thylakoid membranes of the maize inbred lines with erect top leaves. The Arrhenius plot is based on the linearization of the exact DF temperature dependence of observed maize inbred lines. Critical temperatures (phase transition temperatures) at which conformational changes occur in chloroplasts and the thylakoid membranes are determined by the application of the Arrhenius plot (Fig. $3 A$ and $B$ ).

Table 1. The angle of the above-ear leaf and the leaf area of maize inbred lines with efficient photosynthetic functions

\begin{tabular}{|c|c|c|c|c|c|c|}
\hline \multirow{2}{*}{ Inbred line } & \multirow{2}{*}{$\begin{array}{l}\text { FAO } \\
\text { maturity } \\
\text { group }\end{array}$} & \multirow{2}{*}{$\begin{array}{l}\text { Heterotic origin } \\
\text { of the inbred }\end{array}$} & \multicolumn{2}{|c|}{$\begin{array}{l}\text { Angle of the above-ear leaf } \\
\text { in degrees }\end{array}$} & \multicolumn{2}{|c|}{$\begin{array}{l}\text { Area of the above-ear leaf, } \\
\qquad \mathrm{cm}^{2}\end{array}$} \\
\hline & & & average angle & $\begin{array}{c}\text { standard } \\
\text { deviation } \sigma\end{array}$ & $\begin{array}{l}\text { average leaf } \\
\text { area }\end{array}$ & $\begin{array}{l}\text { standard } \\
\text { deviation } \sigma\end{array}$ \\
\hline ZPPL 218 & 650 & $\begin{array}{l}\text { Zemun Polje - } \\
\text { Lancaster }\end{array}$ & $22.1^{\circ}$ & 1.36 & 391 & 0.41 \\
\hline ZPPL 318 & 600 & $\begin{array}{c}\text { Zemun Polje - } \\
\text { BSSS }\end{array}$ & $21.2^{\circ}$ & 1.15 & 358 & 0.39 \\
\hline
\end{tabular}



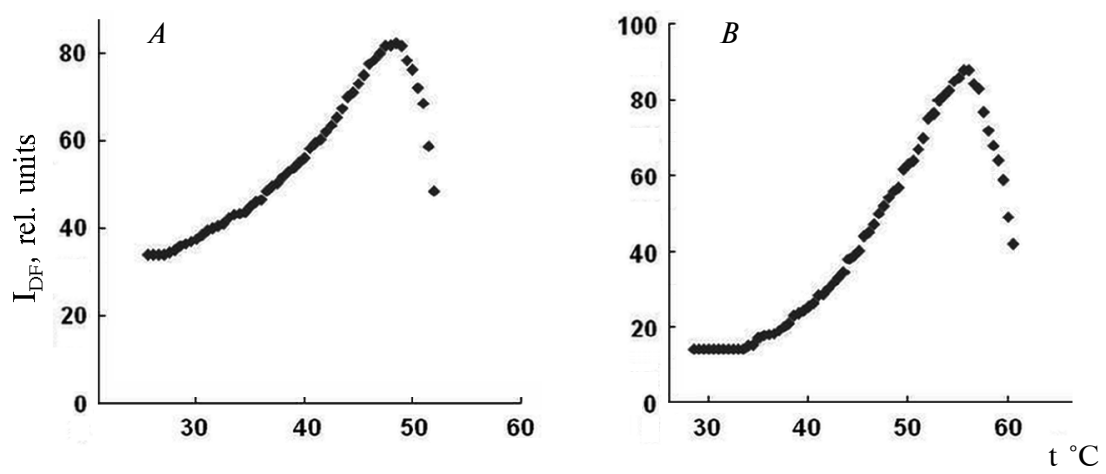

Fig. 2. Changes in the intensity of the delayed chlorophyll fluorescence $\left(\mathrm{I}_{\mathrm{DF}}\right)$ of thermal processes in dependence on the effects of temperatures on chloroplasts and thylakoid membranes of the intact above-ear leaf of maize inbred lines with erect top leaves: ZPPL $218(A)$, and ZPPL $318(B)$
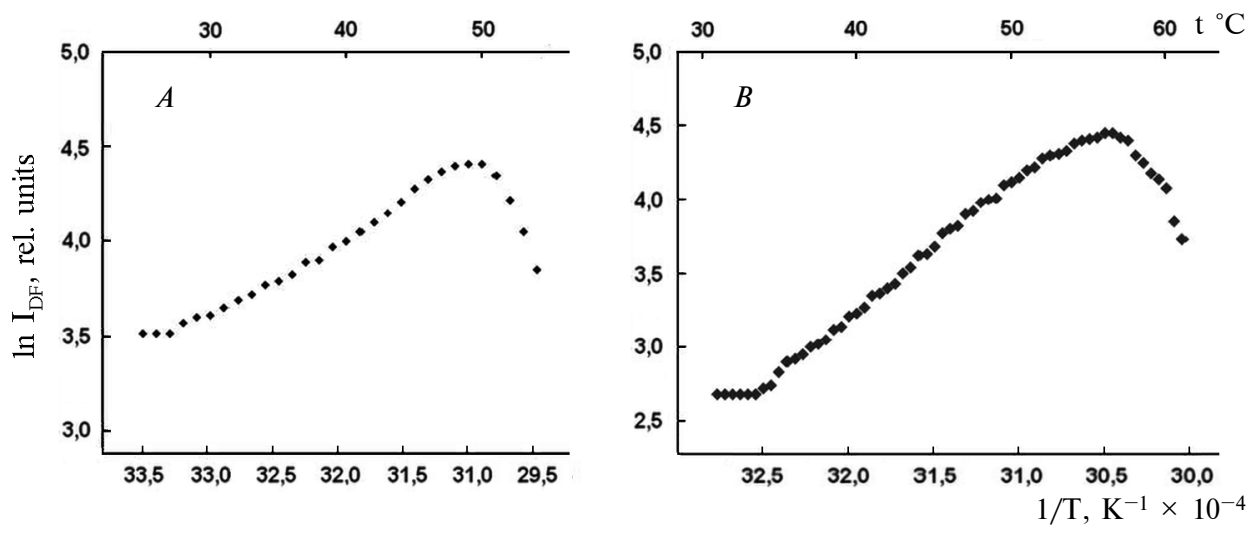

Fig. 3. The Arrhenius plot for the determination of critical temperatures (T, K) and conformational changes in chloroplasts and thylakoid membranes of the above-ear leaf of observed maize inbred lines with erect top leaves: ZPPL $218(A)$ and ZPPL $318(B)$

5. Activation energy and critical temperatures in the thylakoid membranes of the observed maize inbred lines with erect top leaves. Detailed studies on the thermal processes of DF, and especially on the analysis of experimental thermal curve, encompassed not only the temperature dependence and the

Table 2. Changes in activation energies (Ea) and critical temperatures $\left(t{ }^{\circ} C\right)$ in the course of thermal processes in the thylakoid membranes of the intact above-ear leaf of studied maize inbred lines with erect top leaves

\begin{tabular}{ccccc}
\hline \multicolumn{2}{c|}{ ZPPL 218} & \multicolumn{2}{c}{ ZPPL 318} \\
\hline $\mathrm{Ea}, \mathrm{kJ} / \mathrm{mol}$ & $\mathrm{t},{ }^{\circ} \mathrm{C}$ & $\mathrm{Ea}, \mathrm{kJ} / \mathrm{mol}$ & $\mathrm{t},{ }^{\circ} \mathrm{C}$ \\
\hline- & 27.0 & - & 33.5 \\
43.1 & 29.0 & 40 & 38 \\
27.3 & 36.9 & 77.23 & 53.5 \\
37.0 & 43.5 & 26.09 & 56.5 \\
42.5 & 47.8 & 50.51 & 59.3 \\
51.1 & 49.9 & 227.52 & - \\
\hline
\end{tabular}

Arrhenius plot, but also the estimation of values of activation energies (Ea) for critical temperatures (phase transition temperatures) in chloroplasts and the thylakoid membranes of the observed new maize inbreds with erect top leaves (ZPPL 218 and ZPPL 318) were carried out (Tab. 2).

6. Yields of new and prospective maize hybrids on different locations in Serbia. New and prospective maize hybrids: ZP 600, ZP 606 and ZP 666, are mainly indented for the cultivation in Banat, Srem, Bačka, Mačva and 
alongside river banks in Serbia. Average grain yields of those hybrids ranged from 11.0 to $11.8 \mathrm{t} / \mathrm{ha}$. Observed hybrids showed high and stabile yields over different locations and environments, which indicates them as perspective hybrids for maize production (Tab. 3).

7. Broad survey of breeding and seed production traits of new maize inbred lines and prospective maize hybrids with efficient photosynthetic functions. Maize inbred lines ZPPL 218 and ZPPL 318 have been included in breeding for the last 3-4 years. As new and prospective maize inbred lines and hybrids with erect top leaves are observed a broader presentation of relevant breeding, seed production and technological traits, properties and parameters gained by use of standard methods is given (Tab. 4).

8. Chemical composition and physical properties of new and prospective maize inbred lines and hybrids with efficient photosynthetic functions. Chemical composition of grain of two inbred lines and their three hybrids encompassed percentage of starch, proteins, oil and crude fibre (Tab. 5). Variations between chemical compositions were observed between inbred lines and also their hybrids. Indices of physical properties of grain of maize inbred lines and hybrids with erect top leaves also show differences between and among them (Tab. 6).

Yield potential is the genome-encoded capacity of a crop species to generate yield in an optimal growth environment [16]. Therefore the canopy architecture has been a major target in crop breeding for improved yields [22]. The second half of the $20^{\text {th }}$ and the first decade of the $21^{\text {st }}$ century are characterised by a great success achieved in maize breeding and the production of fundamental and hybrid maize seed of high quality and commercial maize. The number of plants per area unit has been growing since 1978. This programme was referred to as a «plant density» programme and it directly affected the yield increase of high quality fundamental and hybrid maize seed [20]. In addition, a programme on the development of maize inbred lines with erect top leaves was established at the same time as the «plant density» programme. It was considered that inbreds with the erect top leaves were the closest to the proposed efficient photosynthetic model $[18,21]$. The complementary and mass implementation of these programmes led to very important results in both, maize breeding and the hybrid seed production. New and numerous hybrids with high grain and silage yields were developed and grown on large areas due to their high yielding potential and the appropriate quality of the plant and the grain $[5,8,22,24]$.

Contemporary breeding studies have been performed on top leaves of maize inbred lines. Ear leaves have been particularly observed, but also other

Table 3. Yields of new and prospective maize hybrids ( $t / h a)$ with efficient photosynthetic functions in eight locations of Serbia*

\begin{tabular}{c|c|c|c|c|c|c|c|c|c}
\hline \multirow{2}{*}{ Hybrid } & \multicolumn{10}{c}{ Locations in Serbia* } \\
\cline { 2 - 10 } & $\frac{1}{x}$ & $\frac{2}{x}$ & $\bar{x}$ & $\frac{4}{x}$ & $\frac{5}{x}$ & $\frac{6}{x}$ & $\frac{7}{x}$ & $\frac{8}{\bar{x}}$ & $\begin{array}{c}\text { Average } \\
\bar{x}\end{array}$ \\
\hline ZP 600 & 12.8 & 11.0 & 11.2 & 12.9 & 11.8 & 10.6 & 10.8 & 13.5 & 11.8 \\
ZP 606 & 12.9 & 11.6 & 10.5 & 12.5 & 10.9 & 10.7 & 10.4 & 12.2 & 11.6 \\
ZP 666 & 12.7 & 10.9 & 9.5 & 11.6 & 10.6 & 10.0 & 10.3 & 12.5 & 11.0 \\
\hline
\end{tabular}

* Locations in Serbia by the ordinal number: 1 - Loznica, western Serbia; 2 - Sakule, southern Banat; 3 - Smederevo, the Danube region; 4 - Zmajevo, southern Bačka; 5 - Žarkovac, eastern Srem; 6 - Batoš, mid Banat; 7 - Divoš, northern Srem; 8 - Bečej, eastern Bačka. 
Č.N. RADENOVIĆ, D.M. GRODZINSKIJ, M.R. FILIPOVIĆ et al.

Table 4. Relevant breeding and seed production traits of maize inbred lines with efficient photosynthetic functions

\begin{tabular}{c|c|c}
\hline \multirow{2}{*}{$\begin{array}{c}\text { Name and defining of } \\
\text { traits }\end{array}$} & $\begin{array}{c}\text { Brief description of breeding, seed production and technological traits of } \\
\text { new maize inbred lines }\end{array}$ \\
\cline { 2 - 3 } & ZPPL 218 & ZPPL 318 \\
\hline
\end{tabular}

Heterotic origin

FAO maturity group

Grain yield in $\mathrm{kg} \cdot \mathrm{ha}^{-1}$

at $14 \%$ moisture
a) dry land farming
b) irrigation

Erect position of ear leaf

Stay green

Inbred tolerance to stress factors such as drought, high temperature and the like

$\%$ moisture in grain at harvest

What does inbred emergence look like?

Is grain suitable for nutrition of ruminants and nonruminants?

What is a content of carotene in inbred grain?

Is the inbred suitable for the development of silage hybrids?

Digestibility (\%)
Zemun Polje - Lancaster

650

$3220 \pm 204$

$4186 \pm 255$

Inbred has an erect top leaves

Stay green trait is medium pronounced. Leaves above ear remain green until waxy ripeness

Inbred has a good tolerance to drought and increased and high temperatures

Inbred is harvested at $18.0 \%$

Inbred emerges very well

Inbred has high quality grain and hybrids developed from this inbred have also high quality grain suitable for nutrition of ruminants and nonruminants

Grain of this inbred has a common content of carotene and hybrids developed from this inbred are very suitable for nutrition of pigs and ruminants

Inbred is very suitable for the development of silage hybrids

81.6

$$
\text { Zemun Polje - BSSS }
$$

$4056 \pm 265$

$6045 \pm 330$

Inbred has a very erect top leaves

Stay green trait is pronounced to a medium extent. Leaves above ear remain green until waxy ripeness

Inbred has a good tolerance to drought and increased and high temperatures

Inbred is harvested at $22.0 \%$

Inbred emerges very well

Inbred has high quality grain and hybrids developed from this inbred have also high quality grain suitable for nutrition of ruminants and nonruminants

Grain of this inbred has a higher content of carotene and hybrids developed from this inbred are very suitable for nutrition of laying hens

Inbred is very suitable for the development of silage hybrids

80.44

Table 5. Chemical composition of new and prospective maize inbred lines and hybrids with efficient photosynthetic functions

\begin{tabular}{l|c|c|c|c}
\hline \multicolumn{1}{c}{ Lines or hybrids } & Starch (\%) & Proteins $(\%)$ & Oil (\%) & Crude fibre (\%) \\
\hline Inbred line & \multicolumn{5}{l}{} \\
$\quad$ ZPPL 218 & 69.10 & 9.60 & 5.79 & 2.18 \\
ZPPL 318 & 71.27 & 10.31 & 4.91 & 2.39 \\
Hybrid & & & & \\
ZP 600 & 73.01 & 7.76 & 5.76 & 1.91 \\
ZP 606 & 73.48 & 9.84 & 5.06 & 2.23 \\
ZP 666 & 74.32 & 9.61 & 6.10 & 2.42 \\
\hline
\end{tabular}


Table 6. Physical properties of the grain of new and prospective maize inbred lines and hybrids with efficient photosynthetic functions

\begin{tabular}{l|c|c|c|c|c|c|c}
\hline Lines or hybrids & TKW $^{*}$ & TW & D & FI & MR & HEF & SEF \\
\hline $\begin{array}{l}\text { Inbred line } \\
\quad \text { ZPPL 218 }\end{array}$ & 341.5 & 844.1 & 1.29 & 23.28 & 10.5 & 58.1 & 41.9 \\
$\quad$ ZPPL 318 & 316 & 811.7 & 1.28 & 24.31 & 12.2 & 62.3 & 37.7 \\
Hybrid & & & & & & \\
$\quad$ ZP 600 & 488.0 & 788.2 & 1.27 & 34.3 & 12.7 & 55.8 & 44.2 \\
ZP 606 & 474.0 & 777.0 & 1.26 & 48.2 & 11.3 & 57.9 & 59.1 \\
ZP 666 & 356.0 & 806.2 & 1.28 & 24.5 & 10.9 & 42.7 & 40.0 \\
\hline
\end{tabular}

${ }^{*}$ TKW $=1000$-kernel weight $(\mathrm{g}), \mathrm{TW}=$ test weight $\left(\mathrm{kg} / \mathrm{m}^{3}\right), \mathrm{D}-$ density $\left(\mathrm{g} / \mathrm{cm}^{3}\right)$, FI floatation index $(\%), \mathrm{MR}-$ milling response $(\mathrm{s}), \mathrm{HEF}-$ hard endosperm fraction $(\%)$, SEF soft endosperm fraction $(\%)$.

top leaves up to the tassel. The most efficient and the longest photosynthetic processes necessary for the maize plant have been achieved by these leaves. According to the stated, a hypothesis that top leaves (above-ear leaves) achieving the efficient photosynthesis has been proposed. Therefore studies of genetic regulation of leaf angle and determination of QTLs responsible for this trait are very important in maize breeding. Several QTLs for leaf angle were determined by linkage mapping and association mapping $[10,11,13,15,24,25$, 26]. The genetic basis of this trait is dominated by small effects with little epistasis, environmental interaction and pleiotropy.

This study was an attempt to answer the following questions by using different tests and analyses:

1) Were there reliable and dominant traits of maize inbred lines with erect top leaves by which planned and satisfactory progress in maize breeding and the high-quality hybrid seed maize production could be achieved?

2) Which traits should such maize inbred lines have?

Gained results of experimental studies can offer at least a partial answer to these questions. The first series of experiments included the measure of the angle and the leaf area of observed new maize inbred lines with erect top leaves. The results obtained on these traits (Tab. 1) classify them into important breeding and seed production traits $[18,19]$. The second series of experiments encompassed photosynthetic fluorescence studies on conformational and functional changes in chloroplasts and the thylakoid membranes of the intact above-ear leaf of new maize inbred lines. The exact results of the temperature dependence of DF for all new maize inbred lines with erect top leaves are presented (Fig. $2 A, B$ ). All critical temperatures (phase transition temperatures) at which even the slightest conformational changes had occurred in the thylakoid membranes of new maize inbred lines with erect top leaves were determined by the Arrhenius criterion and the linearization of the DF temperature dependence. The values of critical temperatures in ${ }^{\circ} \mathrm{C}$, their frequency and intermediate distance characterise observed maize inbred lines with erect top leaves in relation to their tolerance, resistance, flexibility and adaptability not only to increased and high temperatures, but also to drought [18].

The Arrhenius criterion is based on the existence of straight lines. Each Arrhenius straight line represents its activation energy (Ea). The intersection point of two straight lines is designated by a critical temperature. Results of the Ea values in the inclining and declining part of the thermal curve are explained 
by lesser or greater conformational changes that occur in the molecules of pigments (chlorophyll) in the thylakoid membrane with the temperature increase. Due to such changes, these molecules become more reactive and thereby gain the additional energy that is used in the recombining process of the DF occurrence (Tab. 2) [17, 18].

Presented photosynthetic fluorescence traits of studied maize inbred lines with erect top leaves can contribute to more exact, rational and expeditious proceedings of breeding processes and the production of high-quality hybrid maize seed, and commercial maize, which makes these maize inbred lines exceptionally important.

Obtained results of maize hybrids yields (Tab. 3), should be considered as preliminary ones. According to the description of breeding, seed production and technological traits, properties and parameters it is obvious that these are stable hybrids with high quality grains. However, it is necessary to find appropriate locations for such hybrids (Banat, Bačka, Srem, Mačva, river valleys, but also in Turkey, Greece, Romania, Mediterranean and Middle East countries) in which their full genetic potential of the yield can be used.

Analysis of physical traits and chemical composition (Tab. 5, 6) indicate exceptional quality of observed maize inbred lines and hybrids with efficient photosynthetic functions [19].

A broad survey of breeding, seed production and technological traits of new inbred lines and prospective maize hybrids with efficient photosynthetic functions (Tab. 4) completes above presented observations and contributes to the improvement of modern programmes of both, breeding and current hybrid seed and commercial maize productions, which can be useful for practice.

\section{Conclusions}

Elite maize inbred lines and hybrids with erect top leaves possess an efficient photosynthetic model. Such inbreds like ZPPL 218 and ZPPL 318 are successfully applied in modern breeding programs and production of high yielding and high quality maize hybrids like ZP 600 ZP 606 and ZP 666. Analysis of agronomic parameters showed that those hybrids perform high and stabile yields over environments and on the other hand possess desirable chemical and physical grain composition. Presented results indicate that favorable properties of maize inbreds and hybrids are in great dependence on nature of structural and functional changes that occur in their chloroplast and thylakoid membranes.

\section{Acknowledgement}

This study was supported by the Ministry of Education, Science and Technological Development of the Republic of Serbia through the Project TR31037.

1. Бухов Н.Г., Рахимбердиева М.Г., Карапетян Н.В. О природе медленных переходных явлений переменной и замедленной флуоресценции листьев // Физиология растений. - 1989. - 36. - С. 1045-1054.

2. Веселовский В.А., Веселова Т.В. Люминесцентная характеристика фотосинтетического аппарата растений // Люминесценция растений: теоретические и практические аспекты. - М.: Наука, 1990. - 201 с.

3. Barber J., Neumann J. An energy conservation site between $\mathrm{H}_{2} \mathrm{O}$ and DBMIB: evidence from msec delayed light and chlorophyll fluorescence studies in chloroplasts // FEBS Lett. 1974. - 40. - P. 186-189. 
4. Ciocazanu I., Terbea M., Micut G., Lazar C. Inheritance of physiological parameters implied in maize drought resistance // Rom. Agr. Res. - 1996. - N 5-6. - P. 57-66.

5. Duvick D.N. The contribution of breeding to yield advances in maize (Zea mays L.) // Adv. Agron. - 2005. - 86. - P. 83-145.

6. Felner M., Ford E.D., van Volkenburgh E. Development of erect leaves in a modern maize hybrid is associated with reduced responsiveness to auxin and light of young seedlings in vitro // Plants Signall. and Behaviour. - 2006. - 1, N 4. - P. 201-211.

7. Govindjee Van Der Ven M., Preston C., Seibert M., Gratton E. Chlorophyll $a$ fluorescence lifetime distribution in open and closed photosystem II reaction centre preparation: Analysis by multifrequency phase fluorometry // Biochem. et Biophys. Acta. Bioenergetics. — 1990. 1015. - P. 173-179.

8. Hallauer A.R. Modern Methods in Maize Breeding // Proceedings of the Workshop on Maize Breeding and Maize Production EUROMAIZE 88, October 6-8, 1988, Belgrade, Yugoslavia. - Belgrade, 1988. - P. 1-20.

9. Jurisnic P. Delayed fluorescence: Current concepts and status // Light Emission by Plants and Bacteria /Ed. Govindjee, Amesz \& Fork CD. - Orlando, Fl. (USA): Acad. Press., 1986. P. 291-328.

10. Ku L.X., Zhang J., Guo S.L., Liu H.Y., Zhao R.F., Chen Y.H. Integrated multiple population analysis of leaf architecture traits in maize // J. Exp. Bot. - 2012. - 63. - P. 261-274.

11. Ku L.X., Zhao W.M., Zhang J., Wu L.C., Wang C.L., Wang P.A., Zhang W.Q., Chen Y.H., Quantitative trait loci mapping of LA and leaf orientation value in maize // Theor. and Appl. Genet. - 2010. - 121. - P. 951-959.

12. Lichtenthaler H.K., Rinderle U. The role of chlorophyll fluorescence in the detection of stress conditions in plants // Crit. Revs Anal. Chem. - 1988. - 19. - Suppl. I. - P. 29-85.

13. Lu M., Zhou F., Xie C.X., Li M.S., Xu Y.B., Marilyn W., Zhang S.H. Construction of a SSR linkage map and mapping of quantitative trait loci (QTL) for LA and leaf orientation with an elite maize hybrid. // Heredita. - 2007. - 29. - P. 1131-1138.

14. Marković D., Jeremić M., Radenović Č., Schara M. Irreversible structural changes in thylakoid membranes at high temperatures detection by luminescence and EPR // Gen. Physiol. Biophys. - 1993. - 12. - P. 37-47.

15. Mickelson S.M., Stuber C.S., Senior L., Kaeppler S.M. Quantitative trait loci controlling leaf and tassel traits in a B73x Mo17 population of maize // Crop Sci. - 2002 _ - 42. - P. 19021909.

16. Patrick J., Colyvas K. Crop yield components - photoassimilate supply- or utilisation limited-organ development? // Funct. Plant Biol. - 2014. - 41, N 9. - P. 893-913.

17. Radenović $\check{C}$. A study of delayed fluorescence in plant models: Photosynthetic transportation and membrane processes // J. Serbian Chem. Soc. - 1994. - 59. - P. 595-617.

18. Radenović Č., Babić M., Delić N., Hojka Z., Stanković G., Trifunović V., Ristanović D., Selaković D. Photosynthetic properties of erect leaf maize inbred lines as the efficient photomodel in breeding and seed production // Genetika. - 2003. - 35, N 2. - P. 85-97.

19. Radenović Č., Grodzinskij D., Filipović M., Radosavljević M., Videnović Ž., Denić M., Čamdžija Z. The prestigious maize inbred lines and hybrids with erect top leaves are characterised by a property of an efficient photosynthetic model and a satisfactory base for the further progress in breeding and selection // Физиология и биохимия культ. растений. -2010 . $-\mathbf{4 2}$, № 3. - C. 187-201.

20. Radenović $\check{C}$., Ristanović D., Trifunović $V$. The theoretical and the development programme on the increase of the plant number per area unit for the development of erect leaf maize lines and for their more effective application in breeding // The internal note, Maize Research Institute, Zemun Polje, Belgrade. - Belgrade, 1978. - P. 1-3.

21. Radenović Č., Šatarić I., Husić I., Mišović M.M., Filipović M., Kojić L. A study of functioning of thylakoid membranes in inbred lines of maize (Zea mays L.) // Genetika. — 2000. - 32, N 3. - P. 377-386.

22. Russell W.A. Contributions of breeding to maize improvement in United States, 1920s-1980s // Iowa State J. Res. - 1986. - 61. - P. 5-34.

23. Song Q., Zhang G., Zhu X.G. Optimal crop canopy architecture to maximise canopy photosynthetic $\mathrm{CO}_{2}$ uptake under elevate $\mathrm{CO}_{2}-$ a theoretical study using a mechanistic model of canopy photosynthesis // Funct. Plant Biol. - 2012. - 40, N 2. - P. 108-124.

24. Sprague G.F. Organization of breeding programs // 20th Ann. Illinois Corn Breeding School (USA). - 1984. - 20. - P. 20.

25. Tian F., Bradbury P.J., Brown P.J., Hung H., Sun Q., Sherry F.G., Rocheford T.R., McMullen M.D., Holland J.B., Buckler E.S. Genome-wide association study of leaf architecture in the maize nested association mapping population // Nature Genetics. - 2011. - 43. P. $159-162$.

26. Yu, Y.T., Zhang J.M., Shi Y.S., Song Y.C., Wang T.Y., Li Y. QTL analysis for plant height and LA by using different populations of maize // J. Maize Sci. - 2006. - 14. - P. 88-92.

ISSN 2308-7099. Физиология растений и генетика. 2016. T. 48. № 5 
27. Zhang J., Ku L.X., Han Z.P., Guo S.L., Liu H.J., Zhang Z.Z., Cao L.R., Cui X.J., Chen Y.H. 2014. The ZmCLA4 gene in the qLA4-1 QTL controls leaf angle in maize (Zea mays L.) // J. Exp. Bot. - 2014. - 65, N 17. - P. 5063-5076.

Получено 25.03.2016

\title{
ЯКЇСНІં ОЗНАКИ ІНБРЕДНИХ ЛІНІЙ КУКУРУДЗИ ТА ЇХ ГІБРИДІВ 3 ЕФЕКТИВНИМИ ФОТОСИНТЕТИЧНИМИ ФУНКЦІЯМИ
}

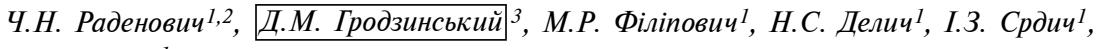 \\ I.M. Павлов ${ }^{1}$ \\ ${ }^{1}$ Науково-дослідний інститут кукурудзи «Земун поле», Белград, Сербія \\ 2 Белградський університет, Сербія \\ ${ }^{3}$ Інститут клітинної біології та генетичної інженерії Національної академії наук України, \\ Київ, Україна
}

Наведено результати досліджень, які підтверджують наявність ефективної фотосинтетичної системи у нових перспективних інбредних ліній кукурудзи та їх гібридів. Ознаки високої ефективності успішно використовують у програмах селекції та сучасних технологіях промислового виробництва кукурудзи. 3 вертикальним положенням верхніх листків у інбредних ліній кукурудзи корелюють значення параметрів, що характеризують активність фотосинтетичного апарату та флуоресценції хлорофілу, а саме: інтенсивність уповільненої флуоресценції хлорофілу та іiі динаміка, критерій Арреніуса щодо критичних температур (температура фазового переходу) та енергія активації як міра конформаційних змін у хлоропластах та їх тилакоїдних мембранах. Наведені дані вказують на те, що господарськоцінні ознаки досліджених інбредних ліній і гібридів насамперед визначаються особливостями конформаційних і функціональних змін, які відбуваються у хлоропластах, зокрема в тилакоїдних мембранах, а також прогресом у селекції та насінництві кукурудзи.

\section{КАЧЕСТВЕННЫЕ ПРИЗНАКИ ИНБРЕДНЫХ ЛИНИЙ КУКУРУЗЫ И ИХ ГИБРИДОВ С ЭФФЕКТИВНЫМИ ФОТОСИНТЕТИЧЕСКИМИ ФУНКЦИЯМИ}

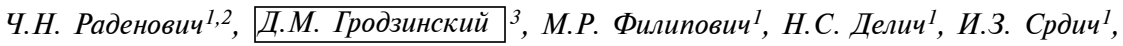
И.М. Павлов ${ }^{1}$

${ }^{1}$ Научно-исследовательский институт кукурузы «Земун поле», Белград, Сербия

2 Белградский университет, Сербия

${ }^{3}$ Институт клеточной биологии и генетической инженерии Национальной академии наук Украины, Киев, Украина

Приведены результаты исследований, которые подтверждают наличие эффективной фотосинтетической системы у новых перспективных инбредных линий кукурузы и их гибридов. Признаки высокой эффективности успешно используются в программах селекции и современных технологиях промышленного производства кукурузы. С вертикальным положением верхних листьев у инбредных линий кукурузы коррелируют значения параметров, характеризующих активность фотосинтетического аппарата и флуоресценции хлорофилла, а именно: интенсивность замедленной флуоресценции хлорофилла и ее динамика, критерий Аррениуса в отношении критических температур (температура фазового перехода) и энергия активации как мера конформационных изменений в хлоропластах и их тилакоидных мембранах. Представленные данные указывают на то, что хозяйственно-ценные признаки исследованных инбредных линий и гибридов прежде всего определяются особенностями конформационных и функциональных изменений, происходящих в хлоропластах, в частности, в тилакоидных мембранах, а также прогрессом в селекции и семеноводстве кукурузы.

Ключевые слова: Zea mays L., замедленная флуоресценция хлорофилла, эффективная фотосинтетически-флуоресцентная модель, тилакоидная мембрана. 